\title{
Factors determining English test score of high school students in rural Nepal
}

Neupane, Pramila

University of Tsukuba, Japan (pramila.neupane.gb@u.tsukuba.ac.jp)

Thapa, Rajesh Bahadur

The International Centre for Integrated Mountain Development (ICIMOD), Nepal (rajesh.thapa@icimod.org)

Sapkota, Jeet Bahadur

University of Tsukuba, Japan (sapkota.jeet.gb@u.tsukuba.ac.jp)

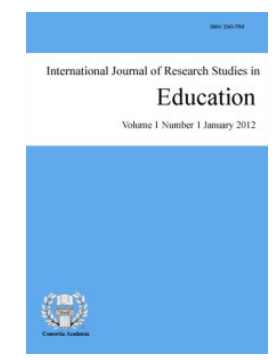

ISSN: 2243-7703 Online ISSN: $2243-7711$

OPEN ACCESS

\section{Abstract}

Due to globalization and internationalization of education, the importance of English language has been growing consistently. Like many other countries around the globe, English is taught as a compulsory subject from the primary level in Nepal. Despite continuous public and private efforts, achievement in English education is not satisfactory, especially in rural areas, due to numerous socio-cultural and other factors. Thus, this article explores some important determinants of English achievement of high school students in Rural Nepal. Through the questionnaire responses of 407 students from the four villages of Sindhupalchok district, which is explored using Cremer's V analysis, a strong association between students' English test score and their socio-cultural, family, school and personal factors was found.

Keywords: English education; questionnaire survey; rural Nepal; test score 


\section{Factors determining English test score of high school students in rural Nepal}

\section{Introduction}

In the contemporary rapidly globalizing world, the importance of English language has been increasing more than ever before. Having a good English skill is considered an added benefit in peoples' lives. It has been found that English is used for most of the cross-border business communications (Nickerson, 2005; Rogerson-Revell \& Louhiala-Salminen, 2010; Evans, 2013). Moreover, English is a language of science. Most of the scientific works including research and publications are in English. Therefore, it is necessary to have a good command of English to excel in the scientific discipline. English is the most commonly used language between international academic communities (Altbach \& Knight, 2007) and a medium of instruction in formal education institutions in different parts of the world, especially, in higher education. If students' command of English is not satisfactory, they may face difficulties in achieving their academic goals of obtaining a university degree from international educational institutions. A great deal of time and money is being spent by people who take various English proficiency examinations such as TOEFL and IELTS which establishes the importance and value of English around the world.

Like many other countries, English is taught as a compulsory subject from the primary school level in Nepal. Recognizing the importance of English in the job market, parents are greatly concerned about their children's English score at school. The importance of having a good grade in English subject creates several opportunities for the students. Therefore, to achieve fluency in English and to obtain good quality education overall, many parents send their children to private schools in cities-paying high tuition fee where the medium of instruction is English. However, in the rural areas, parents do not have any other choice than to send their children to the only public schools available in the local area, even if the quality of education is not that good compared to private schools. With these and various other factors, English learning is not always an encouraging prospect for students in rural Nepal.

To be more specific, socio-cultural and geographical diversity brings variations in English scores of the students in Nepal. There is a big gap between the overall achievement of students of private and public schools in Nepal (Parajuli \& Das, 2013; Khadka, 14 June 2016). In private schools, learning English is emphasized with English being the medium of instruction. Therefore, students in private schools achieve proficiency in the English subject. However, the public schools present a different scenario. English is considered to be one of the most difficult subjects and student achievement in English is not encouraging compared to private schools. Moreover, the achievements in the language greatly vary between male and female students. For instance, in the nationwide School Leaving Certificate examination of the year 2015, though the girls taking the exam were more than boys, the boys outperformed the girls (Ghimire, 2015).

Researchers and educational practitioners alike have been consistently making an effort to study the various determinants of student achievement. Coleman's report on the "equality of educational opportunities" has emphasized the importance of family determinants of student achievement, which includes parental education, occupation and household income (Coleman, Campbell, Hobson, et al., 1966; Glick \& Sahn, 2000; Tansel, 2002). Similarly, socio-cultural determinants such as gender and ethnic background of the students also have significant influence on student achievement (Chesters \& Daly, 2015).

In this scenario, this research aims to identify the determinants of English score of high school students in Rural Nepal. It finds the strength of the association between English scores and the socio-cultural, family, school and personal determinants using Cramer's V analysis. 


\section{Study area}

The study area of this research was chosen using purposive sampling techniques. As this study is focused on rural Nepal, Sindhupalchowk district was selected because it is one of the most under-developed districts in terms of socio-economic indicators (Neupane, 2012). Moreover, since the study focuses on remote villages with diverse ethnic composition, four villages that met the criteria were selected. The selected four VDCs included in the study are Lisankhu, Piskar, Tauthali and Thokarpa. Sindhupalchowk district on the map of Nepal and four selected villages for the study are marked in Figure 1.

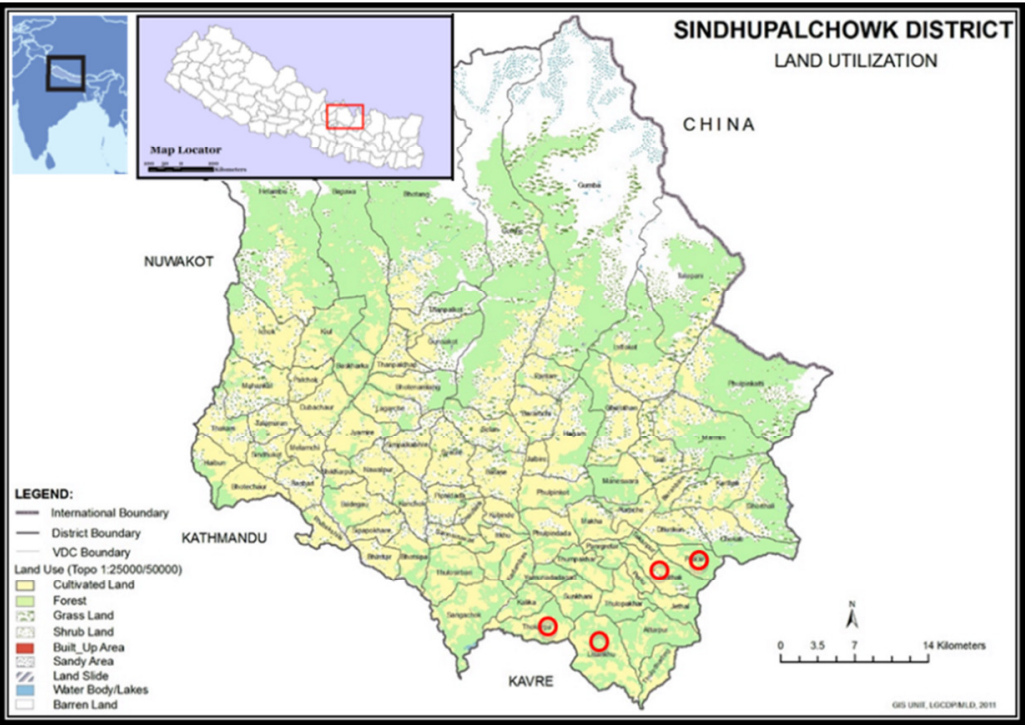

Situated in the southeastern part of Sindhupalchowk District, Lisankhu VDC has a population of 6,160 (District Development Committee (DDC) Sindhupalchowk, 2010), with a majority of Tamang (66\%) people; whereas Piskar VDC in the eastern corner of the district has a population of 2,686 with 36 percent being Thami. Tauthali is one of the oldest villages in Sindhupalchowk that has a population of 5,355 with the majority of Newar (87\%). Another village, Thokarpa, which is well-known for its community forestry, has a mixed population composition with a total of 6,243 people. This VDC has a majority of Brahman and Chhetri people with a significant number of Silpi population. Sindhupalchowk district on the map of Nepal and four selected villages for the study are marked in Figure 1.

\section{Data and method}

\subsection{Data collection and processing}

The major portion of data in this study was collected using quantitative techniques. A questionnaire survey was the main technique used to collect the data from the students of selected high schools. Moreover, the test scores of Grade 9 and 10 students were collected from each selected school of the four VDCs. The collected data was later coded and processed using MS Excel and STATA software.

Developing questionnaire - Mostly, close-ended questions were used to obtain information about students' background characteristics, for both boys and girls, along with their perceptions of schooling experiences. The questions were designed in the Likert scale (Likert, 1932). The Likert scale is a psychometric scale, which is the most widely used approach to scale responses in research. When responding to a question in a Likert questionnaire, respondents specify their level of agreement or disagreement on a symmetric agree-disagree scale for a series of statements. Thus, the range captures the intensity of their feelings or perceptions for a given question. The questionnaire was designed with three sections, which had a total of 25 questions. The questions 
were intended to collect the information on 1) student's background information; 2) information on schooling experiences, and, 3) information on gender, caste and ethnic barriers. The questionnaire was initially developed in English and translated into Nepali before it was implemented in the field.

Selection criteria for village, school and level of students - Because of its typical nature of representing the traditional socio-economic conditions in hills and mountainous rural area of Nepal, the Sindhupalchowk district has been selected for the study. From this district, four villages (Lisankhu, Piskar, Tauthali, and Thokarpa) were selected by purposive sampling to achieve the objective of the study. Lisankhu is selected because the village has a majority of the Tamang ethnic group, which is also the majority within the district. Piskar village is selected because it also has one of the endangered ethnic groups called Thami, and it is a very remote village in the district with no access by road. Tauthali village is also very remote with no road access with a majority of the Newar ethnic group. Newar is the most advanced ethnic group among Janajatis with their population concentrated in the capital city of Kathmandu and other urban areas. However, the situation of Newars in rural area is rarely explored. Therefore, it could be an interesting inquiry to explore Newars' education situation in the countryside. Finally, Thokarpa village is selected because it has a significant number of one of the endangered ethnic groups called Pahari, and the village has a mixed population composition.

All the secondary and higher secondary schools from the four selected villages were included in the study. Lisankhu and Thokarpa have two schools; Piskar and Tauthali each has one school. This is how the number of selected schools is not same in each village. List of the selected schools is presented in Figure 2.

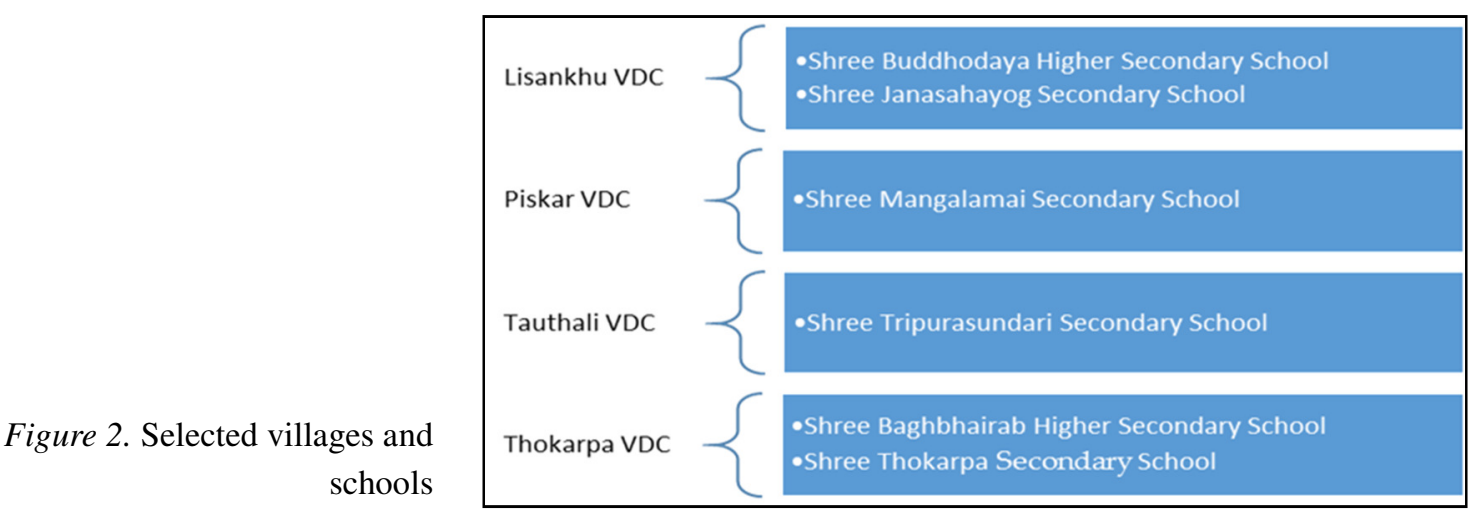

Out of eight schools in Lisankhu VDC, Shree Buddhodaya Higher Secondary School and Shree Janasahayog Secondary School were selected for the study. Out of five schools in Piskar village, only one secondary school, Shree Mangalamai Secondary School, was selected for the detailed study. Similarly, Shree Tripurasundari Secondary School from Tauthali VDC, Shree Baghbhairab Higher Secondary School, and Shree Thokarpa Secondary School from Thokarpa VDC were selected for the study.

Among the three different levels of school education in Nepal, high school level was selected for this study because this stage is the most critical stage in school education. At this level, the students are mature enough to independently take part in the survey. Moreover, one of the determining factors of English test score is gender, and gender-based parameters are easily visible to high school level students compared to lower levels. As the high school children are in their teenage, girls start facing more barriers from their family, society and school.

Census survey - Census survey was conducted to collect complete information from all of the participants in the population. Though census survey takes a great deal of time, energy and financial resources, it gives exact and accurate results (Barro \& Lee, 2013). The four VDCs were selected from relatively least remote to the most remote village in the rural context, and also based on the main ethnic group in each village. For instance, Thokarpa is the least remote village, and Piskar is the most remote village. The remaining two villages are moderately remote. Similarly, Piskar has the highest population of one of the marginalized ethnic group Thami, Tauthali has the Newar ethnic group in majority, Lisankhu has the Tamang ethnic group, and Thokarpa has a mix 
of major ethnic groups. Newars in Tauthali village comprise the largest sample population with 150 students whereas Pahari in Thokarpa represent the smallest number in the sample, i.e., two.

Figure 3 presents the distribution of respondents by village, gender and caste/ethnicity. Among seven caste/ethnic groups (presented in bar graph), Newar has the largest population of both male and the female students. Similarly, Chhetri is the second and Tamang is the third. The lowest number of population is of Pahari with only two Pahari boys in Thokarpa village. In total, Thokarpa has the largest sample population with 32 percent (presented in pie chart). Similarly, Lisankhu, Piskar and Tauthali has 30 percent, 12 percent and 26 percent sample population, respectively. Genderwise total is 58 percent female and 42 percent male.

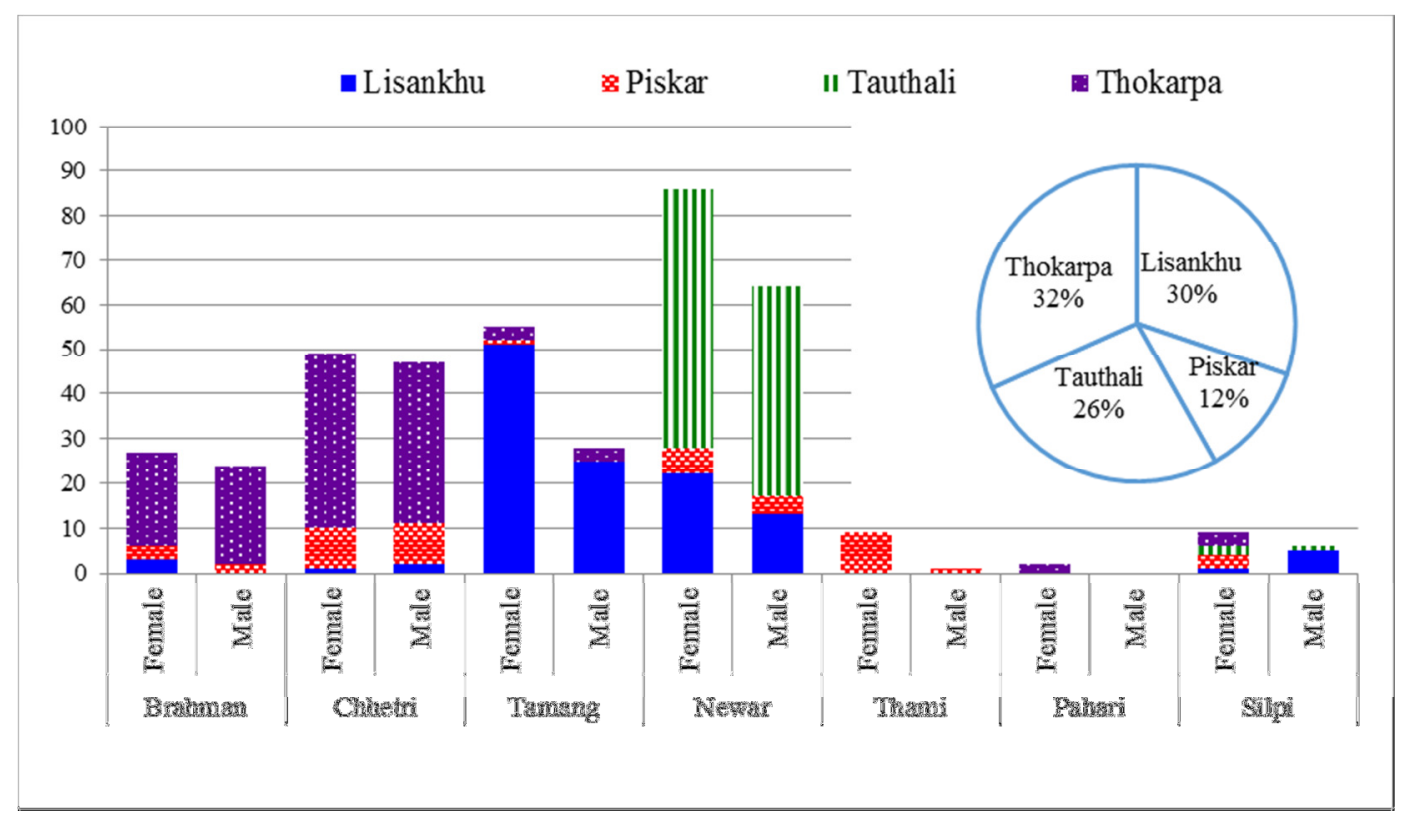

Figure 3. Village wise sample distribution by caste/ethnic group and gender. Pie chart represents proportion of sample population.

\subsection{Determinants of English test score}

Many studies have investigated the factors contributing to students' school achievement (Coleman, et al., 1966; Lloyd, 1994; Lu \& Treiman, 2008; Chesters, 2015). For the purpose of this study, we have identified 12 factors that have a significant influence on students' overall achievement as well as in English subject learning. These determinants are divided into four categories and presented in Table 1.

Table 1

Prospective determinants of English achievement

\begin{tabular}{c|l|l}
\hline 1 & Socio-cultural determinants & Gender \\
& & Caste and ethnicity \\
\hline 2 & Family determinants & Mother's education \\
& & Father's education \\
& & Land sufficiency \\
& & Advance goods in family \\
& & Study time at home \\
& & Household chores \\
& & Number of siblings \\
\hline 3 & School determinants & Teachers' help in class \\
\hline 4 & Personal determinants & Future ambition \\
& & Desired level of education \\
\hline
\end{tabular}


Selection of determinants - A large body of empirical literature examines the association between student's test score and various influencing factors ranging from family inputs to school inputs. Education development experts unanimously agree on the groundbreaking findings of Coleman et al. (Hanushek, 2016) that family has a strong influence on student achievement. The pioneering report measured family background which included parents' education, family size, advance goods at home, study material and study time at home, including other such factors. Several variables for our study have been identified based on this well-cited study. Specifically, all the variables in category one and two in Table 1 are related to the family background in one way or the other. Many other subsequent studies after Coleman have used family background measures, and they are found to have a strong association with students' achievement (Güvendir, 2015; Chesters, 2015). In a study of African countries, Chinyoka and Naidu (Chinyoka \& Naidu, 2014) found that girls were required to perform a variety of household chores which hindered them from having enough time for study and therefore resulting in poor academic performance. This finding is in-line with many other studies which uncover that students who perform many household chores spend little time on studies leading to poor school performance. In many families in Asia and Africa, doing household chores and helping their parents are highly prioritized than their academic performance (Aslam, 2009; Okeke, Nzewi, \& Njoku, 2012).

Researchers have been studying sibling structure such as number of siblings, birth order and birth spacing on student achievement. In most of the studies, number of siblings has a negative effect on student's achievement, especially in developed countries (Heer, 1985; Kuepie, Tenikue, Nouetagni, \& Misangumukini, 2014). Moreover, this negative relation is generally explained by "resource dilution hypothesis," in which it is argued that limited family resources are distributed among siblings reducing family resources to each child (Blake, 1981; Downey, 1995). However, this negative effect is not universal. In developing countries, particularly, it is dependent on various non-family related factors (Lloyd, 1994; Vida, 2008). Studies from China, India and Malaysia reveal that when the school education is subsidized by the state, there is less effect of parental resources and number of siblings (Sudha, 1997). In a society with a strong son preference, when there are limited resources in the family, parents prefer to invest in the education of sons rather than daughters (Sudha, 1997; Tansel, 2002; Parish \& Willis, 1993; Chu, Xie, \& Yu, 2007). Andrabi, Das, Khwaja, Vishwanath, and Zajonc (2007) found that student achievement is lower when there are many older brothers but not when there are many older sisters. It has also been found that children from a bigger family with more siblings perform relatively poorly, because the family resources need to be divided among many children. Aslam (Aslam, 2009) in a study of a case of Pakistan found that children's aspiration about how much education they wanted was closely associated with their academic achievement.

Family's socio-economic background is also a strong determinant of student achievement. Parental education, occupation, possession of goods, land sufficiency, is found to have a strong association with student achievement. In education research, the effect of socio-economic status (SES) of the family is one of the commonly examined factors because a family has a strong role in children's educational achievement. Parents with higher levels of SES have more financial and social resources to invest in education (Becker, 1975), which results in their children demonstrating higher levels of performance (Veenstra \& Kuyper, 2004). The common variables used to measure parent's SES are parent's education, occupation and income. The idea in support of this argument is that these children have greater access to financial and social resources compared to families with a lower level of parental education. Parental education is a strong determiner of student achievement as educated parents provide motivation and encouragement to their children. Moreover, educated parents can assist their children in their studies and homework (Dundar, Béteille, Riboud, \& Deolalikar, 2014).

Land sufficiency and possession of advanced goods by the family are two proxies that can be used to measure the family resources. The family possessing advanced goods and having sufficient or more than sufficient land means the family is rich enough which indicates that they have a supportive learning environment and the family can expend the necessary educational cost on their children. In a study, Stash and Hannum (Stash \& Hannum, 2001) found that land ownership was strongly associated with school attendance in Nepal. 
All the variables identified and discussed earlier potentially affect secondary level students' achievement in the Nepalese rural society. These variables are household chores that students need to perform on a daily basis, land sufficiency as almost all villagers depend on agriculture, and ethnic composition of the community where the school is located as the community is highly diverse ethnically, but live together as a mixed population comprising different sets of ethnicities. It is an empirical question as to whether these variables matter. National performance assessment of Grade 8 conducted by the Department of Education in Nepal in 2008 found that students' competence level is not satisfactory in Mathematics as well as English (Dundar, Béteille, Riboud, \& Deolalikar, 2014). The study found that students' achievement is lower in English comprehension and reading compared to their mother tongue.

\subsection{Data processing}

The data collected from the questionnaire survey was coded to eliminate the personal identification of the respondents and entered in MS Excel for analysis. Furthermore, a dataset was created in STATA and analyzed. The two techniques used for data analysis were descriptive analysis and presentation of the data and Cramer's V analysis. The result of the analysis is presented with descriptive data, frequency table, charts and figures in the Result and Discussion section.

\subsection{Cramer's V analysis}

Cramer's V is one of the most popular and commonly employed statistic method to measure the association between two variables being at least is nominal. Cramer's V is calculated using the following equation.

$$
V=\sqrt{\frac{x^{2}}{N(K-1)}}
$$

Where, the Chi-square test statistics, $x^{2}=\sum \frac{F_{O}-F_{E}}{F_{E}}, N$ is the number of observation and $K$ is the numbers of rows or column.

The range of Cramer's $\mathrm{V}$ is between 0 to 1 in which the value close to 0 is no association and value close to 1 is a strong association. The values below 0.15 are considered very weak and hence are not acceptable for the analysis, whereas a value above 0.15 is minimally acceptable. However, any value above 0.2 is acceptable, and the ones above 0.3 are very desirable — such large values indicate a very strong association between the variables.

\section{Results and discussion}

\subsection{Descriptive analysis}

Table 2 presents the summary statistics of the variables used in the study. Twelve various factors, which might have an association with English test score of the students, were selected. English test score is the independent variable of the study. Categorical variables (gender and caste/ethnicity) are not included in the table. The mean of the English test score is below 50, whereas the minimum and maximum values are 27 and 80 , respectively.

Parental education is one of the strong determinants of student achievement (Vellymalay, 2011). Therefore, respondents were asked about both their parents' educations with eight options; 0 for no father/mother, 1 for illiterate, 2 for just literate, 3 for primary level, 4 for secondary level, 5 for technical diploma, 6 for certificate level, and 7 for bachelor or higher degree. The mean score for father's education is 2.36, which means fathers are 
either just literate or have primary level education on average. On the other hand, the mothers' education level is lower than fathers', with a mean score of 1.57 , which means mothers are either illiterate or just literate on average. Notably, we found that more than 19 percent of the respondents have illiterate fathers and more than 53 percent of the respondents have illiterate mothers. Similarly, five respondents have their fathers with university education whereas only one respondent said his/her mother has a university level education. The results not only indicate the very poor educational status in the society, but also show a big gender gap in education.

\section{Table 2}

Summary statistics

\begin{tabular}{lcccc}
\hline Variable & Mean & SD & Min. & Max. \\
\hline Father's education & 2.36 & 1.22 & 0 & 7 \\
Mother's education & 1.57 & 0.83 & 0 & 7 \\
Land sufficiency & 11.72 & 3.20 & 0 & 15 \\
Number of advanced goods & 3.22 & 1.30 & 0 & 7 \\
Time given to study at home & 3.28 & 1.14 & 1 & 5 \\
Time given for household chores & 3.45 & 1.39 & 1 & 9 \\
Number of siblings & 4.39 & 1.65 & 1 & 10 \\
Desired level of education & 3.02 & 1.06 & 1 & 4 \\
Teachers' additional support & 3.21 & 0.98 & 1 & 4 \\
English test score & 45.99 & 9.53 & 27 & 80 \\
\hline
\end{tabular}

Land ownership or its sufficiency to feed the family is one of the commonly used indicators to measure the economic status of a household in any agrarian rural society (Sharma, Upreti, \& Müller-Böker, 2014). Thus, to evaluate the economic status of the family of the respondent, we asked "How enough is the annual agricultural production of your own land to consume for your family?" The options of answers given to them were, 0 for "no land", 6 for enough for about six months, 9 for enough for about nine months, 12 for just enough for the whole year, and 15 for if they can sell the products after fulfilling their family's consumption requirement. The mean score of this variable is 11.72 , which indicates that the agricultural production is nearly good enough for the consumption in average. However, it should be noted that nearly 1.5 percent and 11.3 percent of the respondents reported that they have either no land or minimal land that can produce sufficiently for only about six months. However, 32.4 percent of the respondents reported that they have surplus food to sell remaining after consumption. This shows a highly unequal land distribution in the society.

The village census data shows that nearly five percent of the households in the villages engaged in other sectors than agriculture. Similarly, the number of technologically advance goods owned by the respondents' family is also used to evaluate their economic status. In the context of the rural peasant society of Nepal, the following seven goods are considered as advanced goods, i.e., television, phone (land line or mobile), radio, rice cooker, pressure cooker, liquid petroleum (LP) cooking gas, and a bio-gas plant. The result shows that respondents' family have three types of advanced goods on average. However, nearly 11 percent and 19 percent of the respondents have just one type and two types of advanced goods, where 24 percent and two percent of the respondents have five types and six types of advanced goods in their family, respectively.

It is intuitive that the overall test score including English also depends on students' studying habit at home or the time they spend doing homework (Keith, Reimers, Fermann, Pottebaum, \& Aubey, 1986). Thus, we asked "in general, what is the average number of hours per day that you study/do assignments at home?" The answer ranged from 1 for less than one hour, 2 for one to less than two hours, 3 for two to less than three hours, to 4 for over four hours. The mean score is 3.28 , which means students study three to four hours on average at home. Similarly, students' time spent on household chores also affects their overall test score including English. Therefore, we also asked "How many hours do you spend doing different household chores at home." The options were one hour to 9 hours. We found that the average time spent on household chores is 3.45 hours. As expected, time spent for study is generally more for boys than girls in most of the ethnic groups and vice versa for the time spent on household chores (Figure 4). Exceptionally, Thami male students spent less time for study 
than female students, and Chhetri male students spent more time for household chores than female students. The reason behind these results is that Thami respondents come only from Piskar village and there was only one Thami male student whereas there were nine Thami female students during the survey. From the interview, we found that most of the Thami boys drop out from school when they are of high school age to earn money and support their family because this ethnic group is one of the highly marginalized ethnic groups in Nepal (Gellner, 2007). Many studies in developing countries have found a strong association of children's involvement in economic activities or household chores and their academic achievement (Akabayashi \& Psacharopoulos, 1999; Heady, 2003; Lancaster \& Ray, 2004).

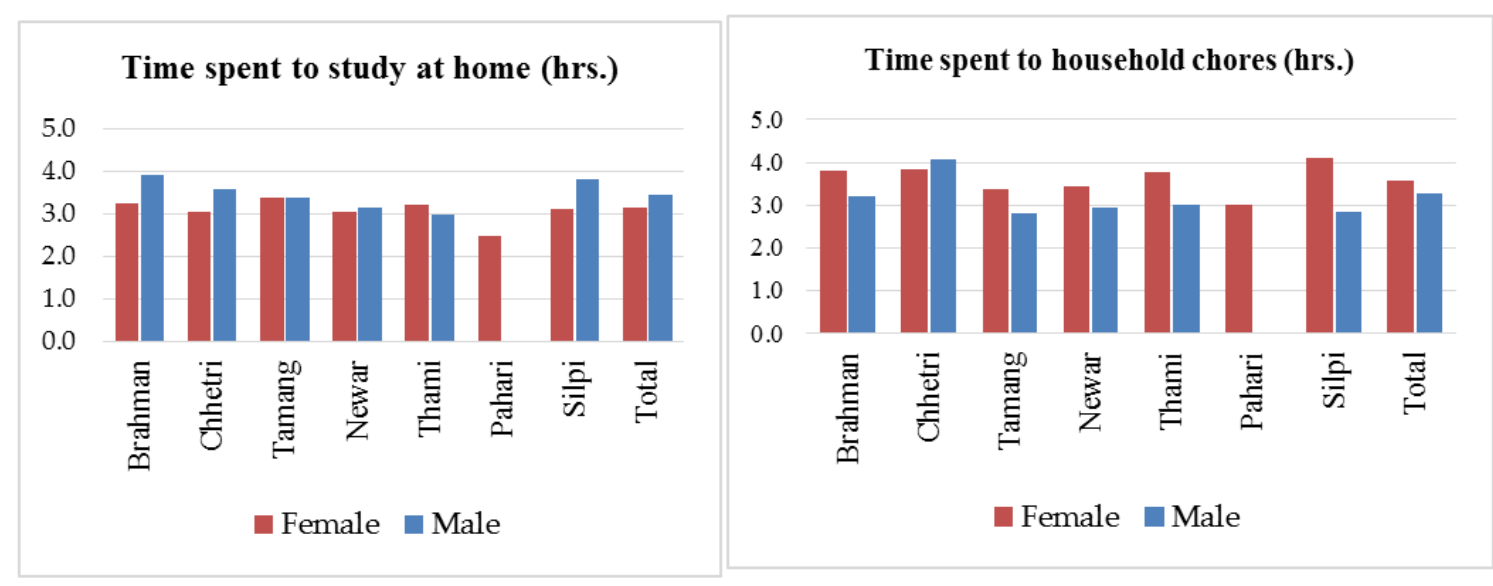

(a): Time spent to study at home (hours)

(b): Time spent to household chores (hours)

Figure 4. Time spent at home by gender and caste ethnic group

As existing literature has already established the poor links between number of siblings and educational performance (Downey, 1995), we also checked whether the number of siblings is associated with the English test score or not. The question asked to the students was "How many brothers and sisters do you have?" The mean score of total number of siblings is 4.39 with minimum of one to maximum of 10 . It means that the students have more than four siblings on average.

A huge body of literature claimed that the school related variables are strongly associated with students' academic achievement (Fuller, 1987; Hanushek \& Woessmann, 2007). However, the unit of analysis of this study is student and the number of schools included is limited to six, which limits the selection of appropriate variables to account for the school factors. Thus, we limit the school factors to only one aspect accounting for the teacher's supporting behavior towards student. To do so, students were given a statement that "If I have problem in my study and perform poor in the class, my teachers provide me extra help." The multiple choices of the answer were 1 for none, 2 for a few, 3 for most, and 4 for all teachers provide help. The mean recorded is 3.21, which means students are getting additional support from most of their teachers in class.

\subsection{Students' English test score}

Figure 5 presents the results of English test scores of the students by gender and caste/ethnic groups (5a) and village (5b). As the highest ranked caste group, Brahman has the highest score with 51 percent, whereas Thami has the lowest score of 36 percent. From the gender perspective, male students outperform female students in all caste/ethnic groups except Tamang. Tamang girls outperform Tamang boys by one percent on average. The biggest gap was found in Thami with 51 percent and 34 percent for male and female students, respectively. The Higher score of females among Tamang is very remarkable and unique. This may be the result of relatively fewer restrictions on girls and women in the Tamang community. Compared to Brahman and Chhetri, Tamang women enjoy more freedom in their family and society. This result shows that achievement difference is based on caste/ethnicity and gender of the students. Students from the high caste group (Brahman) performed better than middle and low caste groups. This result is consistent with Pangeni's (Pangeni, 2014) findings that student 
achievement is related to gender and caste/ethnicity of students. Jamison and Lockheed (Jamison \& Lockheed, 1987) also found that caste membership is one of the strong determiners of student achievement in Nepal.

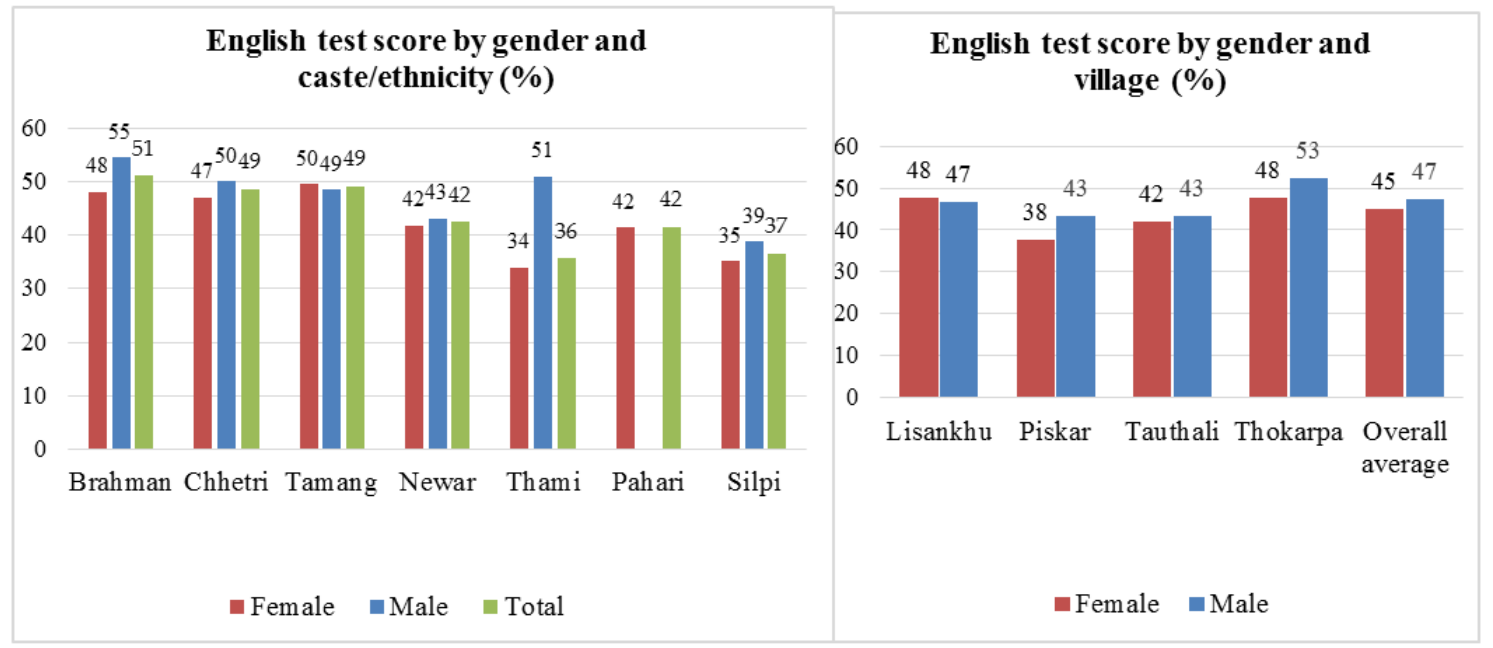

(a): Test score by gender and caste/ethnicity

(b): test score by gender and village

Figure 5. English test score by gender, caste/ethnicity and village (\%)

Figure 5(b) illustrates the average English test score by village and gender. Interestingly, female students in Lisankhu village outperform male students by one percent. This is because Lisankhu has a majority of Tamang ethnic group and females in the Tamang community enjoy more freedom, which creates a study friendly environment for the girl students at home and school. Moreover, Piskar has the lowest score for female students with 38 percent. Piskar and Thokarpa both have five points difference in male and female student scores. Thokarpa village, which has a majority of Brahman and Chhetri students, has the highest score for male students. As for the female students, both Lisankhu and Thokarpa have the same average score of 48. In a study of mathematics achievement of students in Nepal, it is found that student gender and ethnicity were strongly associated with their mathematics achievement (Pangeni, 2014).

\subsection{Cramer's V analysis}

Table 3 presents the association of English test score and its determinants using Cramer's V analysis. We found a very strong association with the Cramer's V value of 0.48 for the caste/ethnic variable. Another socio-cultural variable, gender, also showed strong association with the English test score. The Cramer's V score for gender is 0.34. English is considered as one of the difficult subjects along with Mathematics and Science in Nepal. Student's achievement in these subjects is not satisfactory, especially in public schools. In general, girls and students from disadvantaged ethnic groups cannot put in enough time and effort on the study. Girls need to perform various household chores. In addition, students from low caste groups are also required to do physical labor work more often and vigorously compared with high caste male students, which eventually results in less time and effort spent on their studies. Moreover, they do not have enough exposure to English outside of the classroom, which is associated with their relatively poor performance in the English subject.

All the family variables also showed strong association with English test score as the Cramer's V value ranges from 0.31 to 0.37 . Another determinant with a strong association is the father's education. The result is in line with the existing literature as Davis-Kean and Pamela (Davis-Kean, 2005) found a significant impact of parental education (both father and mother) on their children's school achievement. Similarly, economic status of a family also affects students' test score significantly particularly in developing countries (Unterhalter, 2005). Thus, land sufficiency and number of advanced goods, which are used as proxy of economic status of the family, also showed strong associations with English test score. 
Factors determining English test score of high school students in rural Nepal

Table 3

Cramer's V measure of association between English test score and its determinants

\begin{tabular}{lcc}
\hline \multicolumn{1}{c}{ Variables } & Cramér's V level of association \\
\hline Gender & Socio-cultural determinants & 0.34 \\
Cast/Ethnicity & & 0.48 \\
& Family determinants & \\
Mother's education & & 0.35 \\
Father's education & & 0.37 \\
Land sufficiency & & 0.37 \\
Number of advanced goods & & 0.31 \\
Time given to study at home & School determinants & 0.35 \\
Time given for household Chores & 0.33 \\
Number of siblings & Personal determinants & 0.33 \\
Getting teachers' special help in difficulties in learning & 0.32 \\
Future career ambition & & 0.35 \\
Desired level of education & & 0.32 \\
\hline
\end{tabular}

Similarly, students' score could be influenced by the use of their time at home. Usually, male students have more time to study and less time for household chores compared to female students in a patriarchal society like Nepal (Aslam, 2009; Chinyoka \& Naidu, 2014). Such environment adversely affects girls' overall test score including English. Furthermore, as a family determinant, the number of siblings also adversely affects the test score as most of the people in rural Nepal are poor and have more siblings; this means lesser resources for education per child.

The school variable also showed strong association with students' score. The Cramer's V value for getting teachers' help in difficulties in learning at the class is recorded as 0.32. As many literatures argued that school inputs are important determinants of the educational outcome (Fuller, 1987), the result supports the argument.

Finally, student's personal characteristics and behavior also play a crucial role in their educational success (Schunk, 1990; Pangeni, 2014). Both students' future career ambition and desired level of education are found to have strong association with their English test score. Whether the students are motivated to learn is also a crucial factor in their educational achievement (Schunk, 1990) because motivated students are encouraged to learn. Children's aspiration about how much education they wanted was closely associated with their academic achievement in Pakistan (Aslam, 2009). An analysis conducted in Nepal found a strong relationship between student motivation and academic performance (Pangeni, 2014).

\section{Conclusion}

Poor English skills are one of the main barriers to youth that push them far from many opportunities. After analyzing the English test score of grade 9 and 10 students, this study found that there is a high disparity among students' English achievement in public schools in rural Nepal. Girls and students from socio-culturally disadvantaged caste/ethnic groups particularly perform badly than boys and students from affluent caste/ethnic groups. After observing the disparity in English test scores, we explored some of the crucial determinants that were identified through literature review and analysis of local context associated with the English test score. In addition, the study also examined the level of association of the determinants and test scores using Cramer's V analysis. The findings of this study are useful to minimize the English skill gaps across gender and caste/ethnicity in the public schools in rural areas.

Through the Cramer's V analysis, we found that there is a very strong association between the sociocultural factors (gender and caste/ethnic identity) and the English test score of students. The strongest association is with 
Neupane, P., Thapa, R. B., \& Sapkota, J. B.

caste/ethnicity with 0.48 points, which suggests that while designing education policies and programs, students from these groups should be prioritized. Not only the access to education, but also the quality education should be addressed to promote inclusive and equitable learning opportunities for all.

Family, school and personal factors also showed strong association with the English test score. A total of eight family determinants were included in the study and all of the determinants are strongly associated with student academic achievement in English. This finding suggests that students' family background should be considered while designing and delivering educational programs in a diverse country like Nepal. Since the focus of this study was from the students' perspective, we could include only one school related determinant in our analysis, i.e., teachers' extra help to students. This variable suggests that we need teachers who pay necessary attention and provide assistance to their students to facilitate better learning and ultimately, good performance of their students. Teachers with appropriate training can handle such students and achieve better results on the subjects they teach.

Students' future ambition and their highest education goal motivate them to study hard and achieve, which ultimately opens up better career prospects. Students who have higher educational aspiration need to get a good grade in English, because the medium of instruction in most of the higher education programs is English. The findings of this study have clear academic as well as practical implications. Learners, teachers, school administrators and other stakeholders can significantly benefit from this study. Once the determining factors of English score and their level of association with other social, school and personal factors are identified, academics and policy makers can work better on educational quality improvement. The research approach is applicable to other society as well where socio-cultural diversity is relatively high, and English is widely learned as a second language.

\section{References}

Akabayashi, H., \& Psacharopoulos, G. (1999). The trade-off between child labor and human capital formation: A Tanzanian case study. The Journal of Development Studies, 35(5), 120-140. https://doi.org/10.1080/00220389908422594

Altbach, P. G., \& Knight, J. (2007). The internationalization of higher education: Motivations and realities. Journal of Studies in International Education, 11(3/4), 290-305. https://doi.org/10.1177/1028315307303542

Andrabi, T., Das, J., Khwaja, A., Vishwanath, T., \& Zajonc, T. (2007). Pakistan: Learning and Educational Achievements in Punjab Schools (LEAPS): Insights to inform the educational policy debate. Retrieved from http://www.leapsproject.org/assets/publications/LEAPS_Report E

Aslam, M. (2009). The relative effectiveness of government and private schools in Pakistan: Are girls worse off? Education Economics, 17(3), 329-354. https://doi.org/10.1080/09645290903142635

Barro, R. J., \& Lee, J. W. (2013). A new data set of educational attainment in the world, 1950-2010. Journal of Development Economics, 104, 184-198. https://doi.org/10.1016/j.jdeveco.2012.10.001

Becker, G. (1975). Human capital. A theoretical and empirical analysis, with special reference to education. NY: National Bureau of Economic Research.

Blake, J. (1981). Family size and the quality of children. Demography, 18, 421-442. https://doi.org/10.2307/2060941

Chesters, J., \& Daly, A. (2015). The determinants of academic achievement among primary school students: A case study of the Australian capital territory. Australian Journal of Labour Economics, 18(1), 131-144.

Chinyoka, K., \& Naidu, N. (2014). Influence of home based factors on the academic performance of girl learners from poverty stricken families: A case of Zimbabwe. Mediterranean Journal of Social Sciences, 5(6), 223-232. https://doi.org/10.5901/mjss.2014.v5n6p223

Chu, C., Cyrus, Y. X., \& Yu, R. (2007). Effects of sibship structure revisited: Evidence from intrafamily resource transfer in Taiwan. Sociology of Education, 80, 91-113. https://doi.org/10.1177/003804070708000201

Coleman, J. S., Campbell, E. Q., Hobson, C. J., McPartland, J., Mood, A. M., Weinfeld, F. D., \& York, R. (1966). 
Factors determining English test score of high school students in rural Nepal

Equality of educational opportunity. Washington, DC: National Center for Educational Statistics.

Davis-Kean, P. E. (2005). The influence of parent education and family income on child achievement: The indirect role of parental expectations and the home environment. Journal of Family Psychology, 19(2), 294-304. https://doi.org/10.1037/0893-3200.19.2.294

District Development Committee (DDC) Sindhupalchowk. (2010). Sindhupalchowk district profile 2067. DDC Sindhupalchowk.

Downey, D. B. (1995). When bigger is not better: Family size, parental resources, and children's educational performance. American Sociological Review, 60(5), 746-761. https://doi.org/10.2307/2096320

Dundar, H., Béteille, T., Riboud, M., \& Deolalikar, A. (2014). Student learning in South Asia: Challenges, opportuniteis and policy priorities. Washington, DC: The World Bank . https://doi.org/10.1596/978-1-4648-0160-0

Evans, S. (2013). Perspectives on the use of English as a business lingua franca in Hong Kong. Journal of Business Communication, 50(3), 227-252. https://doi.org/10.1177/0021943613487073

Fuller, B. (1987). What school factors raise achievement in the Third World? Review of Educational Research, 57(3), 255-292. https://doi.org/10.3102/00346543057003255

Gellner, D. N. (2007). Caste, ethnicity and inequality in Nepal. Economic and Political Weekly, 42(20), 1823-1828.

Ghimire, B. (2015, June 20). 47.43 pc students pass SLC test. The Kathmandu Post. Retrieved from http://kathmandupost.ekantipur.com/news/2015-06-20/4743-pc-students-pass-slc-test.html

Glick, P., \& Sahn, D. E. (2000). Schooling of girls and boys in a West African country: the effects of parental education, income, and household structure. Economics of Education Review, 19(1), 63-87. https://doi.org/10.1016/S0272-7757(99)00029-1

Güvendir, E. (2015). A multi-level simultaneous analysis of how student and school characteristics are related to students' English language achievement. Education Research and Perspectives, 42, 491-527.

Hanushek, E. A. (2016). What matters for student achievement. Education Next, 16(2).

Hanushek, E. A., \& Woessmann, L. (2007). The role of education quality for economic growth. Policy Research Working Paper; No. 4122. Washington DC: World Bank. https://doi.org/10.1596/1813-9450-4122

Heady, C. (2003). The effect of child labor on learning achievement. World Development, 31(2), 385-398. https://doi.org/10.1016/S0305-750X(02)00186-9

Heer, D. (1985). Effects of sibling number on child outcome. Annual Review of Sociology, 11, 27-47. https://doi.org/10.1146/annurev.so.11.080185.000331

Jamison, T., \& Lockheed, M. (1987). Participation in schooling: Determinants and learning outcomes in Nepal. Economic Development and Cultural Change, 35(2), 279-306. https://doi.org/10.1086/451586

Keith, T. Z., Reimers, T., Fermann, P., Pottebaum, S., \& Aubey, L. (1986). Parental involvement, homework and TV time: Direct and indirect effects on high school achievement. Journal of Educational Psychology, 78, 373-380. https://doi.org/10.1037/0022-0663.78.5.373

Khadka, K. S. (2016, June 14). Still a lot to learn. The Kathmandu Post. Retrieved from http://kathmandupost.ekantipur.com/news/2016-06-14/still-a-lot-to-learn-20160614080732.html

Kuepie, M., Tenikue, M., Nouetagni, S., \& Misangumukini, N. (2014). Number, age composition and school achievements of siblings in two African capital cities. Oxford Development Studies, 42(4), 534-552. https://doi.org/10.1080/13600818.2014.902046

Lancaster, G., \& Ray, R. (2004). Does child labour affect school attendance and school performance? Multi country evidence on SIMPOC data. Econometric Society 2004 Australasian Meetings, 68. Retrieved from http://EconPapers.repec.org/R

Likert, R. (1932). A technique for the measurement of attitudes. Archives of Psychology, 140, 1-55.

Lloyd, C. (1994). Investing in the next generation: The implications of high fertility at the level of the family. In C. R. (Ed.), Old debates and new conclusions (pp. 181-202). Washington, D.C.: Overseas Development Council.

Lu, Y., \& Treiman, D. J. (2008). The effect of sibship size on educational attainment in China: Period variations. American Sociological Review, 73(5), 813-834. https://doi.org/10.1177/000312240807300506 
Neupane, P., Thapa, R. B., \& Sapkota, J. B.

Neupane, P. (2012). Barriers to education and school attainment across gender, caste and ethnicity: A case of secodnary school in rural Nepal. Unpublished PhD dissertation, Waseda University, Tokyo, Japan.

Neupane, P. (2013). Barriers to education and its impacts. LAP LAMBERT Academic Publishing.

Nickerson, C. (2005). English as a lingua franca in international business contexts. English for Specific Purposes, 24(4), 367-380. https://doi.org/10.1016/j.esp.2005.02.001

Okeke, E., Nzewi, U., \& Njoku, Z. (2008). Tracking school age children's education status in UNICEF A-Field States. Enugu: UNICEF.

Pangeni, K. P. (2014). Factors determining educational quality: Student mathematics achievement in Nepal. International Journal of Educational Development, 34, 30-41. https://doi.org/10.1016/j.ijedudev.2013.03.001

Parajuli, D. R., \& Das, T. (2013). Performance of community schools in Nepal: A macro level analysis. International Journal of Scientific \& Technology Research, 2(7), 148-154.

Parish, W. L., \& Willis, R. J. (1993). Education, and family budgets: Taiwan experiences. Journal of Human Resources, 28, 863-98. https://doi.org/10.2307/146296

Rogerson-Revell, P., \& Louhiala-Salminen, L. (2010). Language matters: An introduction. Journal of Business Communication, 47(2), 91-96. https://doi.org/10.1177/0021943610364510

Schunk, D. H. (1990). Goal setting and self-efficacy during self-regulated learning. Educational Psychologist, 25, 71-86. https://doi.org/10.1207/s15326985ep2501_6

Sharma, S. R., Upreti, B. R., \& Müller-Böker, U. (2014). Negotiating access to land in Nepal. Journal of Contemporary Asia, 44(3), 521-539. https://doi.org/10.1080/00472336.2013.868022

Stash, S., \& Hannum, E. (2001). Who goes to school? Educational stratification by gender, caste, and ethnicity in Nepal. Comparative Education Review, 45(3), 354-378. https://doi.org/10.1086/447676

Sudha, S. (1997). Family size, sex composition and children's education: Ethnic differentials over development in peninsular differentials over development in peninsular Malaysia. Population Studies, 51, 139-151. https://doi.org/10.1080/0032472031000149876

Tansel, A. (2002). Determinants of school attainment of boys and girls in Turkey: Individual, household and community factors. Economics of Education Review, 21(5), 455-470. https://doi.org/10.1016/S0272-7757(01)00028-0

Unterhalter, E. (2005). Global inequality, capabilities, social justice and the Millennium Development Goal for gender equality in education. International Journal of Educational Development, 25(2), 111-122. https://doi.org/10.1016/j.ijedudev.2004.11.015

Veenstra, R., \& Kuyper, H. (2004). Effective students and families: The importance of individual characteristics for achievement in high school. Educational Research and Evaluation, 10(1), 41-70. https://doi.org/10.1076/edre.10.1.41.26302

Vellymalay, S. K. (2011). A study of the relationship between Indian parents' education level and their involvement in their children's education. Kajian Malaysia, 29(2), 47-65.

Vida, M. (2008). The changing relationship between family size and educational attainment over the course of socioeconomic development: Evidence from Indonesia. Demography, 45(3), 693-717. https://doi.org/10.1353/dem.0.0013 